Journal of the Optical Society of Korea, Vol. 16, No. 4, December 2012, pp. 386-395

DOI: http://dx.doi.org/10.3807/JOSK.2012.16.4.386

\title{
Retraction note: Alleviating Light Leakage in LCDs via Diverse Modifications of Polarizer Film
}

\author{
Il Jeon ${ }^{1}$, MinSung Yoon ${ }^{1}$, and Je-Hoon $\mathrm{Lee}^{2 *}$ \\ ${ }^{I}$ KITECH, Kangwon National University, Joongang-ro, Samcheock 245-711, Korea \\ ${ }^{2}$ Division of Electronics and Information, Communication Engineering, Kangwon National University, \\ Joongang-ro, Samcheock 245-711, Korea
}

(Received August 20, 2012 : revised October 11, 2012 : accepted October 26, 2012)

※ "Alleviating Light Leakage in LCDs via Diverse Modifications of Polarizer Film" has been retracted at the request of the authors and by the Code of Research Ethics of OSK after the review of Research Ethics Committee.

*Corresponding author: jehoon.lee@kangwon.ac.kr 